\title{
The role of epidermal growth factor receptor in non-small cell lung cancer
}

\author{
Epidermal growth factor reseptorünün küçük hücreli olmayan akciğer kanserindeki rolü
}

\author{
Ayşe Feyda Nursal
}

\begin{abstract}
Lung cancer is the most common reason of cancer mortality all over the world. Although smoking is the most important factor in lung cancer etiology, additionally, environmental, genetic and occupational factors also contribute to this disease. Despite the fact that there have been progress in lung cancer area in terms of treatments, it has still poor prognosis. Lung cancer is generally classified into two major histological types; small cell lung cancer and non-small cell lung cancer. Non-small cell lung cancer (NSCLC) accounts for approximately $85 \%$ of all cases of lung cancer. Epithelial growth factor receptor mutations are among the most common mutations in NSCLC. These mutations are more prevalent in lung cancer patients who are non-smokers, female, and of Asian ethnicity and tumors which have these mutations response better to tyrosine kinase inhibitors in NSCLC. In this review, the prognostic and predictive role of EGFR will be evaluated in NSCLC.
\end{abstract}

Key words: Non-small cell lung cancer, epidermal growth factor receptor, tyrosine kinase inhibitors

\section{LUNG CANCER}

Lung cancer is the leading cause of mortality in the world since it causes more than one million deaths [1]. However the most significant factor is smoking, there are various risk factors for lung cancer, including asbestos, radon, occupational-environmental exposure and genetic factors [2]. Viruses can have roles in the pathogenesis of lung cancer. Large cell lymphoepithelial lung carcinoma is a rare variant of large cell carcinoma and it is associated with Epstein-Barr virus. Despite the progress in its

\section{ÖZET}

Akciğer kanseri tüm dünyada en yaygın görülen kanser nedenli ölüm sebebidir. Etyolojide sigara en önemli risk faktörü olmasına karşın çevresel, genetik, mesleki faktörlerin de hastalığa katkıda bulunur. Tedavi alanında son yıllardaki tüm gelişmelere rağmen kötü prognoza sahiptir. Akciğer kanseri genellikle histolojik tipine göre küçük hücreli akciğer kanseri ve küçük hücreli olmayan akciğer kanseri olarak iki ana tipe ayrılır. Küçük hücreli olmayan akciğer kanseri tüm vakaların yaklaşık \%85'ni oluşturur. Küçük hücreli olmayan akciğer kanserinde en sık rastlanılan mutasyonlardan biri epidermal büyüme faktör reseptör mutasyonlarıdır. Bu mutasyonlar sigara içmeyenlerde, kadınlarda ve Asya ırkında daha fazladır ve bu mutasyona sahip tümörler tirozin kinaz inhibitörlerine daha iyi cevap verir. Bu derlemede epidermal büyüme faktörün küçük hücreli olmayan akciğer kanserindeki öngörüsel ve prognostik rolü değerlendirilecektir.

Anahtar kelimeler: Küçük hücreli olmayan akciğer kanseri, epidermal büyüme faktör reseptörü, tirozin kinaz inhibitörleri

treatment, prognosis is still not very satisfactory. This poor prognosis depends on the high metastasis and aggressively features of tumors [3]. Due to its heterogenous and complex nature, clarification of the molecular structure (genetic, epigenetic and protein expression) is informative for the diagnosis, prognosis and targeted therapies in lung cancer [4]. Lung cancer is divided into two groups in terms of its histological background. Non-small cell lung cancer (NSCLC) is $85 \%$ and small cell lung cancer (SCLC) is $15 \%$ of all lung cancer cases $[5,6]$.

Giresun Üniversitesi Tip Fakültesi Tıbbi Genetik AD Giresun, Türkiye

Yazışma Adresi /Correspondence: Ayşe Feyda Nursal, Giresun Üniversitesi Tıp Fakültesi Tıbbi Genetik AD Giresun, Türkiye Email: feydanursal@hotmail.com

Geliş Tarihi / Received: 10.11.2014, Kabul Tarihi / Accepted: 06.01.2015

Copyright @ Dicle Tıp Dergisi 2015, Her hakkı saklıdır / All rights reserved 


\section{Non-small cell lung cancer (NSCLC)}

The majority of lung cancers are NSCLCs which are divided into three groups; adenocarcinoma (AC), squamous cell carcinoma (SqCC) and large cell carcinoma. AC and SqCC constitute more than 70\% of NSCLCs [1]. Early stage cancer patients (Stage IA-IIIA) are approximately $25 \%$ of all NSCLCs and the best curative treatment is surgery resection but more than $65 \%$ NSCLCs relapse in two years. In 1970s, only support therapy was recommended for late stage cancer patients but in 1980s platinum chemotherapy started has been started to be applied in patients [7]. But in the present day, there are specific agents developed for histologically-type targeted therapy [5]. Majority of NSCLC patients are diagnosed as in advanced stage and the five years survival rate is only $16 \%$ despite the advances in treatment of this cancer. The mean life span of patients who are in the late stage of NCSLC varies from 9 to 12 months [5].

\section{Gene mutations in NSCLC}

NSCLC frequently shows genetic and epigenetic aberrations. Gene aberrations can be seen in the epidermal growth factor receptor (EGFR), anaplastic lymphoma kinase (ALK), Kirsten rat sarcoma viral oncogene homolog (KRAS), ROS1, rearranged during transfection (RET), MET, echinoderm microtubule-associated protein like (EML4), fibroblast growth factor receptor1(FGFR1), phosphatase and tensin homolog (PTEN) and phosphatidylinositol-4,5-bisphosphate 3-kinase (PI3K) [3].

\section{BASIC BIOLOGY OF EGFR GENE}

EGFR is another known HER1. It is a member of the ErbB family, which consists of four closely related receptors such as HER1/ErbB1, HER2/ErbB2, HER3/ErbB3 and HER4/ErbB4 [8]. These four receptors resemble each other structurally but they have some different features. EGFR is located on chromosome $7 \mathrm{p} 12$, encodes a $170 \mathrm{kDa}$ membrane glycoprotein. EGFR protein consists of a N-terminus extracellular ligand-binding site, a hydrophobic transmembrane domain and a C-terminus intracellular region with tyrosine kinase activity. When the specific ligand binds [for instance; epidermal growth factor (EGF)], it forms a homodimer or heterodimer with the other member of Erb family. Dimerization of EGFR leads to thyrosine kinase phosphorylation. Phosphorylated EGFR activates cell signaling pathways involved in the regulation of cell cycle, cell proliferation and survival via activation of RAS/ MAPK and PIK3CA/AKT pathways [4, 9].

EGFR is normally expressed in various epithelial, mesenchymal and neural origin tissues [10]. EGFR behaves as a proto-oncogene. The EGFR deregulation is common in a variety of tumor subtypes including lung, head and neck, colon, pancreas, breast, bladder, kidney and gliomas [10].

\section{The role of EGFR gene in NSCLC}

EGFR mutations in NSCLC were first identified in 2004. NSCL tumors can show abnormalities such as over expression, amplification and mutation in EGRF gene [7]. NSCL tumors overexpress wildtype EGFR whereas it is not associated with poor prognosis [7]. EGFR mutations are known as an activating mutations and upregulation of oncogenic cell signalling occurs due to the tyrosine kinase ligand-independent activation induced by these mutations. EGFR activating mutations are present in $\% 10-20$ of advanced NSCLC patients. Out of these mutations, more than $\% 50$ of them are adenocarcinomas. Tumors are seen more frequently in East Asians, non-smokers and women more than others [7]. EGFR mutations, concerned to NSCLC, are located within the ATP binding site of the kinase. The most frequent EGFR mutations are in-frame deletions (around amino acid residues 747 to 750 ) of exon 19 (45\% of EGFR mutations) and the exon 21 L858R mutation (40\% of EGFR mutations) [8]. Both mutations account for nearly $80-90 \%$ of the EGFR mutations detected. Besides, less common mutations are the insertions of residues in exon 20 and substitutions at the glycine residue at position 719 in exon $18[7,11]$. The single tumor frequently (3-7\%) includes double EGFR mutations (also named as complex EGFR mutations) [11].

It has been shown that EGFR activation have important roles in cell proliferation, apoptosis, angiogenesis and metastasis of lung tumors [12]. It has been indicated in in vitro studies that the mutations that activate EGFR lead to tyrosine kinase activation and oncogenic transformation in lung epithelium cells [13]. Besides, it has been shown that the in- 
duction of most common EGFR mutations gave rise to the development of small molecule drug sensitive multiple lung adenocarcinomes [14]. Additionally, EGFR overexpression and gene amplification were seen in NSCLC [15]. EGFR amplification is measured by fluorescence in situ hybridization (FISH) analysis [7].

Brain metastasis as well as primary lung adenocarcinoma can also exhibit EGFR mutations and it has been stated that these EGFR mutations lead to carcinogenesis in the early onset of the disease and also metastatic tropism to the brain [16]. The same mutation is seen in brain metastasis rather than the EGFR-mutated NSCLCs [11]. Besides, EML4ALK fusion accompanied with mutations in the EGFR, KRAS, and ERBB2 genes [17].

Zhang et al. have conducted meta-analysis to understand whether EGFR mutations present in advanced non-small cell lung cancer (NSCLC) treated patients that can be related to objective response rate (ORR), progression-free survival (PFS), and overall survival (OS). According to their results, it can be suggested that EGFR mutation can be related to responses to chemotherapy (only ORR was seen to be significantly higher in patients with EGFR mutations) [18].

\section{Testing for EGFR mutations}

Upon PCR amplification, Sanger sequencing of exon sequence was performed in tumor DNA samples in order to detect EGFR mutations. This method is accepted as a gold standard method whereas there are some disadvantages such as limited sensitivity, changing according to sample preparation method and depending on tumor sample amount. Therefore, another PCR method rather than direct sequencing can be used in which tumor or blood samples can are used [7]

\section{EGFR TARGETED TREATMENT IN NSCLC}

The aim in late stage cancers is to diminish the symptoms and increase the life quality and overall survival (OS). Chemotherapeutic drugs have narrow therapeutic index and they are frequently used in palliative treatment. However, in the last decade progress in this topic has become the most important event in major medical area. Histopathologi- cal subtyping of tumors can give the possibility to choose the appropriate molecular test and treatment [19]. Nonspecific toxicity of treatment protocols targeting cancer specific molecules and pathways is relatively less compared to standard therapies.

There are two basic mechanisms with respect to anti-EGFR therapy in clinical use. One is monoclonal antibodies specific to extracellular region where ligand binds (cetuximab, panitumumab). So that, binding and dimerization of the receptor and related signal pathway can be prevented [20]. Upon completing the Human Genome Project (HGP), it has been realized that more than $\% 20$ of human genes code the proteins which have roles in signal pathways. There are more than 500 kinases which can specifically and reversibly control protein phosphorylation. Malign transformation occurs as a result of mutations, genetic aberrations, disruption of signal transduction and dysregulation of expression and activity. Protein kinases are divided into subclasses such as tyrosine and serine/threonine according to their catalytic region [21].

Tyrosine kinases are enzymes which catalyzes the transfer of $\gamma$ phosphate region of adenosine triphosphate to target protein. They play a critical role in the modulation of growth factor signaling and in various cellular events. Activated forms of these enzymes can cause increase in tumor cell proliferation and growth, induce antiapoptotic effects, and promote angiogenesis and metastasis. The other therapy with respect to EGFR depends on the inhibition of these enzymes by tyrosine kinase inhibitors (TKIs). EGFR-TKIs are small molecules that act by inhibiting EGFR autophosphorylation.

\section{EGFR- TKIS}

The development of EGFR-TKIs was a great improvement in the treatment of specific cases of advanced NSCLC [18]. First-generation TKIs such as erlotinib and gefitinib was first used in 2004 in the late stage NSCLC treatment [22]. These drugs compete each other in order to bind to adenosine triphosphate (ATP) reversibly which is located in tyrosine kinase domain of EGFR. So that, tyrosine phosphorylation and signal pathway activation can be prevented [23]. The tumor's response against the first generation EGFR-TKIs is $52-82 \%$ [24]. 
The starting time of the therapy and the treatment period of the EGFR targeted TKIs depend on the specific EGFR mutations. The mutations in exon 19 and 21 are found to be highly sensitive to reversible EGFR-TKIs. Therefore, the FDA limits the usage of erlotinib or afatinibin in cancers which carry these mutations. EGFR-TKIs are less sensitive in rare mutations such as exon 20 mutations, exon 19 insertions, exon 21 missense mutations and exon 18 point mutations [25]. Mutations in response to EGFR-TKIs treatment are shown in Table 1.

Table 1. Mutations in response to EGFR-TKIs treatment

\begin{tabular}{ll}
\hline EGFR-TKIs & EGFR-TKIs \\
sensitive mutations & resistant mutations \\
\hline Exon 19 deletion/insertion & Exon 20 insertion \\
Exon 21 L858R & Exon 20 T790M \\
\hline
\end{tabular}

Afatinib and dacomitinib are the second generation tyrosine kinase inhibitors. They block all the ligands in HER family and form irreversible bonds with their targets. By doing this, they irreversbily inhibit the binding of ATP to tyrosine kinase domain. Second generation TKIs are more efficient compared to first generation ones in the therapy related to EGFR mutations since this inhibition continues lifelong.

Generally, it has been predicted that KRAS mutations are hard to target for the effective EGFRTKIs therapy and the association between KRAS mutation and the EGFR-TKIs treated patients' progression-free survival (PFS) or overall survival (OS) values. However, the retrospective studies suggest that KRAS mutation may have roles in the resistance against the disease [26].

In a study, Zhao et al. determined that whether EGFR-TKI is effective enough as a second-line treatment in EGFR wild-type NSCLC. In order to do so, the group used randomized controlled trial to compare the EGFR-TKI treatments between previously treated advanced NSCLC with wild-type EGFR cases. The endpoints were progression-free survival (PFS), overall survival (OS), and objective response rate (ORR). As a result, they have found that only PFS but not OR can be improved by this type of second-line treatment in advanced NSCLC with wild-type EGFR [27].

\section{EGFR-TKIs and de novo resistance}

The best known mechanism of de novo resistance to EGFR-TKIs is mutation in the KRAS oncogene. This mutation is present in 20 to $30 \%$ of lung cancer patients. Another reason for resistance is the insertion mutations in the exon 20 of EGFR. According to in vitro studies, EGFR exon 20 insertions lead to oncogenic transformation and EGFR-TKIs resistance [3].

\section{EGFR-TKIs and acquired resistance}

Acquired TKIs resistance is a serious problem and is developed within patients within one year who respond to EGFR-TKIs treatment initially. There are various reasons for this.

Firstly, Kobayashi et al. and Pao et al. have described the T790M missense mutation in acquired TKIs resistance in 2005 [28,29]. T790M is a point mutation occured by a single nucleotide substitution $(\mathrm{C}>\mathrm{T})$ at the position of 2369 (codon 790) in 20 exon of EGFR [19].

The most common event responsible for resistance is T790M mutation. There are patients who have resistance to EGFR-TKIs therapy by carrying a second-site mutation T790M ('gatekeeper mutation'). This mutation is located in the kinase domain of the EGFR together with EGFR activating mutation [9]. The T790M mutation leads to a substitution of threonine to methionine in the catalytic centre of EGFR tyrosine kinase, which is located in the binding domain of TKIs and ATP [30]. T790M mutation has been detected in almost $50 \%$ of the cases which exert resistance [29,31]. Other less frequent mechanisms include secondary mutations within EGFR gene. These mutations are exon 19 L747S and D761Y and exon 21 T854A [8]. Tumor cells develop acquired resistance against EGFR-TKIs therapy due to tumor heterogenity [32], MET amplification [9], activation of alternative pathways such as IGF-1, HGF, PI3CA, AXL [33], mesenchimal cell transformation [34]. Interestingly, some of the TKIs resistant tumors can show nonhistological changes such as non-small cell type to small-cell type transitions and epithelial to mesenchimal transitions which can lead to resistance [35]. Apart from these, BRAF mutation, HER2 amplification can also be the reason for this resistance [35]. Acquired resistance mechanisms have not yet been explained 
for the almost $\% 30$ of the all cases [9]. Causes of 2 different types of EGFR-TKIs resistances are summarized in Table- 2 .

Table 2. Causes of different types of EGFR-TKIs resistances

\begin{tabular}{ll}
\hline $\begin{array}{l}\text { Causes of } \\
\text { de novo resistance }\end{array}$ & Causes of acquired resistance \\
\hline KRAS mutation & T790M mutation in exon 20 \\
Exon 20 insertion & MET amplification \\
& Seconder EGFR mutation \\
& BRAF mutation \\
& HER2 amplification \\
& Mesenchimal cell transformation \\
& Small cell histologic transformation \\
& Unknown \\
\hline
\end{tabular}

\section{POTENTIAL THERAPEUTIC STRATEGIES FOR ACQUIRED RESISTANCE TO EGFR- TKIS}

Patients have different tumors with different molecular alterations that can lead to resistance to TKIs therapy. There is a comprehensive study conducted with rebiopsies from TKIs therapy resistant EGFRmutant tumors. The results of this study can be valuable in order to solve the treatment difficulties due to these known and sometimes unpredictable molecular alterations resulting in the TKIs resistance [9].

Some criteria were developed and decided to use in clinics in 2010 [9]. Second- and third-generation TKIs have been developed in order to overcome with EGFR-TKIs resistant tumors. These TKIs generally irreversible multikinase inhibitors to cope with the resistance that is important in the EGFR-TKIs treatment [16].

Cases that have T790M missense mutation do not respond to first generation TKIs. Second generation TKIs such as afatinib and dacomitinib can irreversibly bind to both wild type EGFR protein and EGFR protein with mutation [35]. Scientists have described recently third generation TKIs (CO1686 and AZD9291). These TKIs are covalent pyrimidine EGFR inhibitors which are 30-100 fold potent against cells with T790M mutation and 100 fold more potent against wild type cells [35].

\section{CONCLUSION}

Cytotoxic drugs are the only one therapeutic agent for years in advanced NSCLC cases. In the late phases tumors become prominent first with their histological and later with their biological types. Specific EGFR mutations are important predictive and prognostic markers in NSCLCs. Since EGFR targeted therapy protocols lead to positive tumor response and prognosis, studies related to this area has become more interesting. It is possible to have personalized cancer therapies in case both genetic and clinical departments have collaborative studies related to cancer, its mechanisms and potential drugs.

\section{REFERENCES}

1. Pikor LA, Ramnarine VR, Lam S, Lam WL. Genetic alterations defining NSCLC subtypes and their therapeutic implications. Lung Cancer 2013;82:179-189.

2. Petersen I. The morphological and molecular diagnosis of lung cancer. Dtsch Arztebl Int 2011;108:525-531.

3. Koudelakova V, Kneblova M, Trojanec R, et al. Non-small cell lung cancer-genetic predictors. Biomed Pap Med Fac Univ Palacky Olomouc Czech Repub 2013;157:125-136.

4. Cooper WA, Lam DC, O'Toole SA, Minna JD. Molecular biology of lung cancer. J Thorac Dis 2013;5:479-490.

5. Vijayalakshmi R, Krishnamurthy A. Targetable "driver" mutations in non small cell lung cancer. Indian J Surg Oncol 2011;2:178-188.

6. Inal A, Karakus A, Kaplan AM, et al. A retrospective evaluation of non-small cell lung carcinoma. Dicle med J 2012;39:552-556.

7. Soria JC, Mok TS, Cappuzzo F, Jänne PA. EGFR-mutated oncogene-addicted non-small cell lung cancer: current trends and future prospects. Cancer Treat Rev 2012;38:416430.

8. Massarelli E, Johnson FM, Erickson HS, et al. Uncommon epidermal growth factor receptor mutations in non small cell lung cancer an their mechanisms of EGFR tyrosine kinase inhibitors sensitivity and resistance. Lung Cancer 2013;80:235-41.

9. Remon J, Moran T, Majem, et al. Acquired resistance to epidermal growth factor receptor tyrosine kinase inhibitors in EGFR-mutant non-small cell lung cancer: a new era begins. Cancer Treat Rev 2014;40:93-101.

10. Ahmed ZA, Moatter T, Siddiqui A, Pervez S. Distribution of EGFR Mutations Commonly Observed in Primary Lung Adenocarcinomas in Pakistan as Predictors for Targeted Therapy. Asian Pac J Cancer Prev 2014;15:7125-7128.

11. Cadranel J, Ruppert AM, Beau-Faller M, Wislez M. Therapeutic strategy for advanced EGFR mutant non-small-cell lung carcinoma. Crit Rev Oncol Hematol 2013;88:477-493. 
12. Chi A, Remick S, Tse W. EGFR inhibition in non-small cell lung cancer: current and future directions. Biomark Res 2013;1:2-7.

13. Greulich H, Chen TH, Feng W, et al. Oncogenic transformation by inhibitor-sensitive and -resistant EGFR mutants. PLoS Med 2005; 2:313-317.

14. Ji H, Li D, Chen L, et al.The impact of human EGFR kinase domain mutations on lung tumorigenesis and in vivo sensitivity to EGFR-targeted therapies. Cancer Cell 2006; 9:485-495.

15. Pendharkar D, Ausekar BV, Gupta S. Molecular biology of lung cancer-a review. Indian J Surg Oncol 2013;4:120-124.

16. Berger LA, Riesenberg H, Bokemeyer C, Atanackovic D. CNS metastases in non-small-cell lung cancer: current role of EGFR-TKI therapy and future perspectives. Lung Cancer 2013;80:242-248.

17. Takahashi T, Sonobe M, Kobayashi M, et al. Clinicopathologic features of non-small-cell lung cancer with EML4ALK fusion gene. Ann Surg Oncol 2010;17:889-897.

18. Zhang Q, Dai HH, Dong HY, et al. EGFR mutations and clinical outcomes of chemotherapy for advanced non-small cell lung cancer: a meta-analysis. Lung Cancer 2014; 85: 339-345

19. Moran C. Importance of molecular features of non-small cell lung cancer for choice of treatment. Am J Pathol 2011;178:1940-1948.

20. Krawczyk P, Mlak R, Powrózek T, et al. Mechanisms of resistance to reversible inhibitors of EGFR tyrosine kinase in non-small cell lung cancer. Contemp Oncol 2012;16:401406

21. Capra M, Nuciforo PG, Confalonieri S, et al. Frequent alterations in the expression of serine/threonine kinases in human cancers. Cancer Res 2006;15:147-154.

22. Li T, Kung HJ, Mack PC, Gandara DR. Genotyping and genomic profiling of non-small-cell lung cancer: implications for current and future therapies. J Clin Oncol 2013;10:1039-1049.

23. Melosky B. Review of EGFR TKIs in Metastatic NSCLC, Including Ongoing Trials. Front Oncol 2014;4:244-249.

24. Chen G, Kronenberger P, Teugels E, et al. Targeting the epidermal growth factor receptor in non-small cell lung cancer cells: the effect of combining RNA interference with tyrosine kinase inhibitors or cetuximab. BMC Med 2012;10:2834.

25. Becker K, Xu Y. Management of tyrosine kinase inhibitor resistance in lung cancer with EGFR mutation. World J Clin Oncol 2014;10:560-567.

26. Metro G, Chiari R, Duranti S, et al. Impact of specific mutant KRAS on clinical outcome of EGFR-TKI-treated advanced non-small cell lung cancer patients with an EGFR wild type genotype. Lung Cancer 2012;78:81-86.

27. Zhao N, Zhang XC, Yan HH, et al. Efficacy of epidermal growth factor receptor inhibitors versus chemotherapy as second-line treatment in advanced non-small-cell lung cancer with wild-type EGFR: a meta-analysis of randomized controlled clinical trials. Lung Cancer 2014;85:66-73.

28. Kobayashi S, Boggon TJ, Dayaram T, et al. EGFR mutation and resistance of non-small-cell lung cancer to gefitinib. N Engl J Med 2005; 352: 786-792.

29. Pao W, Miller VA, Politi KA, et al. Acquired resistance of lung adenocarcinomas to gefitinib or erlotinib is associated with a second mutation in the EGFR kinasedomain. PLoS Med 2005;2:73-78.

30. Yang SH. Molecular basis of drug resistance: epidermal growth factor receptor tyrosine kinase inhibitors and anaplastic lymphoma kinase inhibitors. Tuberc Respir Dis 2013;75:188-198.

31. Berger LA, Riesenberg H, Bokemeyer C, Atanackovic D. CNS metastases in non-small-cell lung cancer: current role of EGFR-TKI therapy and future perspectives. Lung Cancer 2013;80:242-248.

32. Saijo N. Present status and problems on molecular targeted. Cancer Res Treat 2012;44:1-10.

33. Zhang Z, Lee JC, Lin L, et al. Activation of the AXL kinase causes resistance to EGFR-targeted therapy in lung cancer. Nat Genet 2012;44:852-860.

34. Nurwidya F, Takahashi F, Murakami A, Takahashi K. Epithelial mesenchymal transition in drug resistance and metastasisof lung cancer. Cancer Res Treat 2012;44:151-156.

35. Nguyen KS, Neal JW, Wakelee H. Review of the current targeted therapies for non-small-cell lung cancer. World J Clin Oncol 2014;10:576-587. 